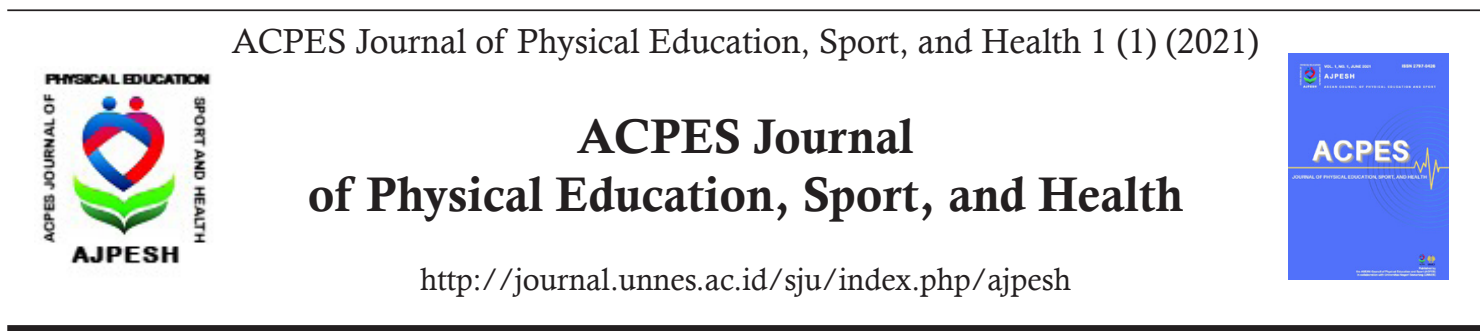

\title{
Development of a Start Basic Engineering Manual (Bunch Start, Me- dium Start, Long Start) for Athletic Court Students
}

\author{
Benny Aprial M. ${ }^{\bowtie}$, Ika Endah Puspita Sari, Ade Evriansyah Lubis, Bobby Helmi, Ri- \\ naldi Aditya
}

Sekolah Tinggi Olahraga dan Kesehatan Bina Guna, Indonesia

DOI: https://doi.org/10.15294/ajpesh.v1i1.46298

\begin{tabular}{|c|c|}
\hline Article Info & bstract \\
\hline $\begin{array}{l}\text { Article History } \\
\text { Submitted } 5 \text { January } 2021 \\
\text { Revised } 22 \text { April } 2021 \\
\text { Accepted } 19 \text { June } 2021\end{array}$ & $\begin{array}{l}\text { This study aims to help provide references aimed at athletic lecturers and students as well as } \\
\text { the general public regarding basic technical materials (Bunch Start, Medium Start, Long Start) } \\
\text { contained in the compulsory courses in every Health and Recreation Physical Education study } \\
\text { program in the form of a technical manual. basic start. The method in this research uses the } \\
\text { method of research and development or Research and Development (R \& D). This research }\end{array}$ \\
\hline $\begin{array}{l}\text { Keywords } \\
\text { athletic skills, ba- } \\
\text { sic start, technique }\end{array}$ & $\begin{array}{l}\text { was conducted in several steps, namely: identification of potentials and problems, information } \\
\text { gathering, product design, product manufacture, expert validation, product revision, testing, } \\
\text { final production. The research subjects were in a small group of } 10 \text { people consisting of } 1 \\
\text { trainer, } 1 \text { athletic lecturer and } 8 \text { students who took basic athletic skills courses and the field tri- }\end{array}$ \\
\hline & $\begin{array}{l}\text { als used } 20 \text { people consisting of } 2 \text { trainers, } 2 \text { lecturers and } 16 \text { STOK Bina Guna students. The } \\
\text { data collection technique used in this study was an instrument in the form of an assessment } \\
\text { sheet. The data analysis technique of this research is descriptive qualitative and quantitative } \\
\text { descriptive. The result of the percentage of this research is the Media Expert of } 94.44 \% \text {, and } \\
\text { the eligibility percentage of the Material Expert is } 98.5 \% \text {. Based on the small group trial, it } \\
\text { was found that the percentage of calibration was } 84.9 \% \text { and the field trial was } 89.85 \% \text {. This } \\
\text { medium is feasible. }\end{array}$ \\
\hline
\end{tabular}

\section{INTRODUCTION}

In fact, learning is a maturing process. By learning, humans can gain knowledge, social, religious, etc. Of course, all of those goes through the learning process. The difficulty of the basic technique of implementing ball materials for most students and the need for animation-based learning media equipped with moving images. The use of animation learning media in learning activities is very helpful in delivering material. Animated media used in learning to deliver material will be more efficient by being packaged in an attractive form so that the teaching material can be used for student learning.

The development and refinement of the mindset states that teacher-centered learning patterns become student-centered learning, learning patterns through learning become network learning and single tool learning patterns become animated me-

Correspondence Author:

Jl. Klumpang Kb, Komplek Sem Regency Mandiri, Kecamatan

e-ISSN 2797-0426

Hamparan Perak Kabupaten Deli Serdang, Indonesia

E-mail: bennyaprial.m@gmail.com 
dia-based learning. Animated learning media or also known as educated media are as follows "educational media are methods and techniques used in order to more effectively communicate and interact between teachers and students in the educational process and running at school" (Fareira, 2014). Based on the statement regarding the problem, this research is expected to be able to solve the existing problem. Students will understand the material with basic basketball techniques, available animationbased learning media, and the learning process that is expected in the 2013 curriculum to be carried out in accordance with the development and refinement of mindset.

Fakhrianto (2018) Running is a basic human movement, running is the movement of moving from one place to another either forward, backward, or sideways. According to Lukman (2003), running and walking are the same, except that the movement in running is emphasized. Two other obvious differences are: (1) in running, there is a short period of time where there is no relationship with the surface. (2) in running, there is no period of time where both feet come into contact with the surface at the same time.

Kridasuwarso (2016) in general has the following attributes: (1) leaning forward, to minimize air resistance coming from the front, runners benefit from more forward weight pointing. This weight point can help with the pull force, so that the stride will be more effective. (2) The footsteps must be longer, step the foot as long as possible at the beginning of the foot away from the starting block, then so that the balance of the body is maintained, the footsteps must start to be slightly shortened but with a fast-moving frequency. (3) when landing the foot; when the foot lands on the affected ground it should always be on the tip of the foot with a slightly bent approach, so that it is flexible when making the next move. (4) motionless; fingers clenched or opened relaxed; hand swing should be coordinated with foot movements. When the left footsteps forward, the left hand must be behind and vice versa when the right footsteps forward, the right hand must be behind.

The elements of running can be divided into three categories, namely: (1) prefix, starting attitude, (2) running; body leaning forward, swinging legs, and swinging arms, (3) posture when finished. This is in line with Manifesting Syarifuddin (1992), "In short distance running there are three techniques that must be implemented and mastered, namely regarding: (a) Start Techniques, (b) Running Techniques, (c) Techniques to cross the finish line (Altuntas et al., 2020).

In a short run (crouching start), the start used is a squat start. In its implementation, there are three kinds of starting squatting techniques, namely, (1) bunch start, (2) medium start, (3) Long start. The use of these three types of start depends and is adjusted on the character of each child.

Start is an initial preparation for a runner to perform a running motion. For short distance numbers, the start used is a crouch start and has 3 types of starts, namely a short start (Bunch Start), a medium start and a long star. The main purpose of starting in running is to optimize the accelerated running pattern. The runner must be able to overcome the inertia by applying maximum force to the start block as soon as possible after the starting gun shot or on cue from the starter and moving into an optimum position for the acceleration stage.

Basic athletic skills are one of the subjects that must be taken by every student in the Health and Recreation Physical Education study program in the second semester at STOK Bina Guna. STOK Bina Guna Campus is a higher education that prepares 
every student to be innovative and have character and become experts in every field of sports (Bahagia, 2012).

The development of a guidebook / module for basic techniques Start in running is deemed necessary so that every student is able to understand every difference of the 3 types of starts in running that can stimulate lecturers and students, including: (1). Teaching styles that are increasingly developing point to students, (2) modules that are always updated according to learning in the era of globalization, (3) learning has standard guidelines, (4) achievement of learning targets is achieved, and (5) the emergence of creativity and innovation in learning. The advantages of using the start technique manual will greatly affect student skills both in terms of movement and learning objectives.

In the basic athletic skills course, for example, most of the lecturers have not been able to assess what the actual goals of learning are. Most lecturers only look at the results of the student's running speed without paying attention to the starting stages themselves which are the most important aspects in running competitions.

Kurniawan \& Hayudi (2018) defines learning media as a communication medium used in teaching and learning activities. In line with this opinion, Degeng stated that teaching media is a component of the delivery strategy that can be loaded with messages that will be conveyed to the learners, whether they are people, tools, or materials.

From these opinions it can be concluded that learning media is any tool, both hardware and software as a communication medium to provide clarity of information. Learning media facilitate the communication of teachers and students in learning and often media are able to stimulate students' thoughts, attention, and desire to learn which encourages students to want to know more about something (Muhtar et al., 2009).

A development in development research is presented in the development procedure section, which usually follows the development adopted by the researcher. Development can also provide a framework for theory development and research. By following a particular model adopted by researchers, a number of inputs will be obtained to improve the resulting product, whether in the form of teaching materials, media, or other products.

The development of the manual for the basic start technique emphasizes students with a model that is easier, more interesting, fun, and not boring so that it can help students learn athletic material easily, especially the basic techniques of starting. consists of basic start techniques that are made in the form of an attractive and innovative book, all products are related to basic start techniques, namely Short Start (Bunch Start), Medium Start and Long Star.

In each product the teacher shows where to position himself so that he can see and improve the product and can convey learning points and progress effectively, so that students can get the best possible benefit from the product.

Based on the description above, it is deemed necessary to develop a running start technique manual. Basically, teaching students must refer to innovation and creativity as well as valid and interesting book sources. For this reason, in this study the researchers tried to develop a Start-and-Run Technique Guidebook Development. 


\section{METHOD}

This type of research is a Research and Development (Research and Development), this research is oriented towards the product being developed. In this development research, the product being developed is the Development of a Start-and-Run Technique Guidebook (Ishak, 2016; Bompa, 2009).

Product design for the development of learning media for the basic technique of basketball for animation is quoted from Borg \& Gall which has the following steps:

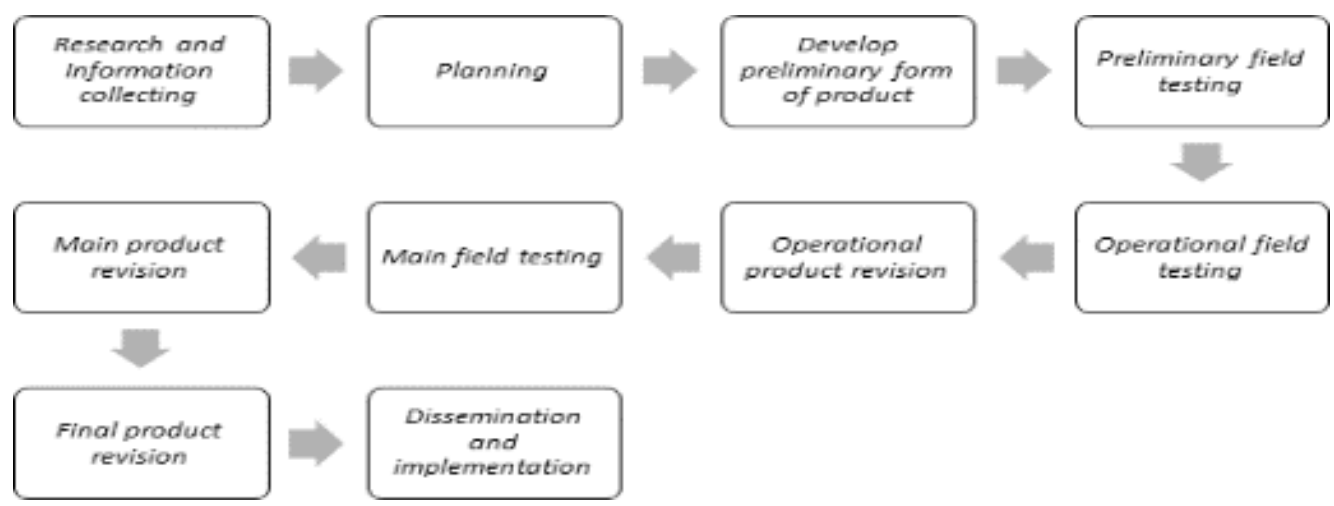

Figure 1. Brog \& Gall's (1983) Development Procedure

\section{RESULT AND DISCUSION}

This study uses the method proposed by Sugiyono (2008). In the stage there are eight steps of product manufacture and research. The first stage is Potentials and Problems, Data Collection, Product Design, Product Manufacturing, Design Validation, Design Revision, Final Products and Product Trials.

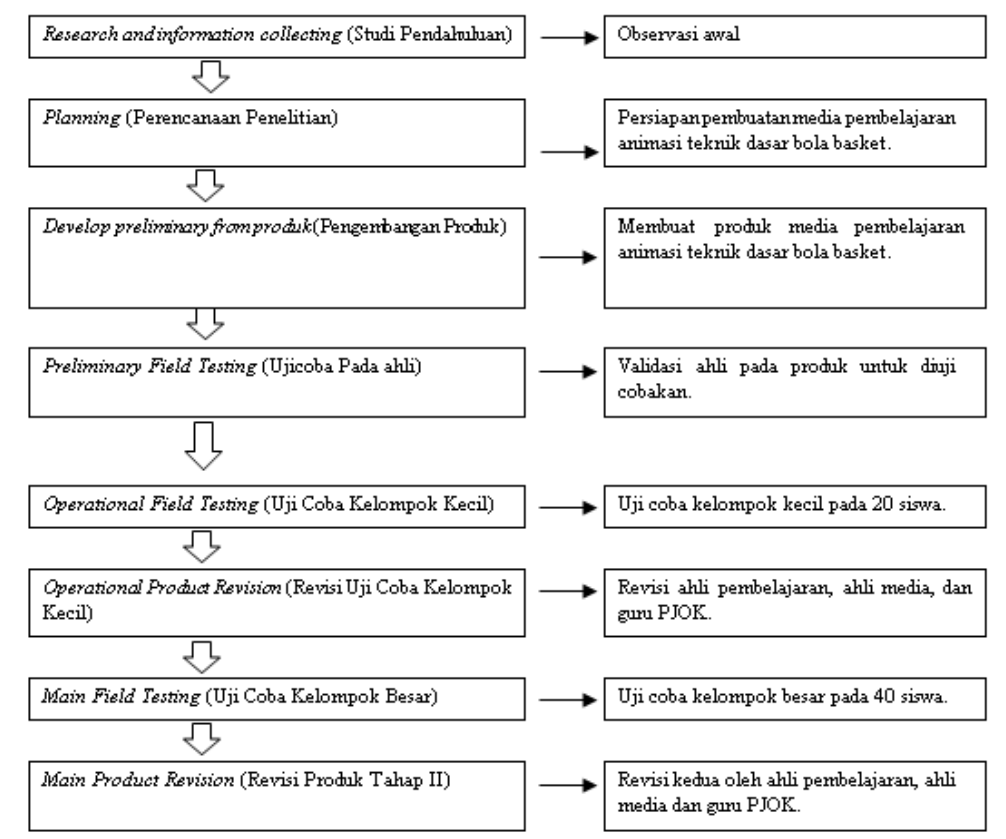

Figure 2. Development Research Stages and Steps. 
Borg \& Gall (1983) proposes a series of steps that must be taken in this approach including 10 general steps, as follows:

1. Research and information collecting: the study of literature related to the problems studied, and preparation to formulate a research framework.

2. Planning: formulating skills and expertise related to the problem, determining the objectives to be achieved at each stage, and if possible / necessary to carry out a limited feasibility study.

3. Develop a preliminary form of product; developing initial forms of the product to be produced, preparation of supporting components, preparing guidelines and manuals, and evaluating the appropriateness of supporting tools. These steps include: (a) Determining the product design to be developed (hypothetical design), (b) determining the research facilities and infrastructure needed during the research and development process, (c) determining the stages of implementing the design test in the field; (d) determine the job description of the parties involved in the research.

4. Preliminary field testing: in this case expert validation is carried out on the product to be tested immediately.

5. Operation Field Testing: conducting initial field trials on a limited scale. by involving as many as 20 research subjects. In this step, data collection and analysis can be done by means of interviews, observations or questionnaires. This step is a limited product test which includes: (1) conducting an initial field test of the product design, (2) having a limited nature, both the substance of the design and the parties involved, and (3) the initial field test is carried out repeatedly so that obtained a feasible design, both substance and methodology.

6. Operational Product Revision, make improvements to the initial products produced based on the results of initial trials. This improvement is very likely to be done more than once, according to the results shown in the limited trial, so that the main product (media) draft is ready to be tested more widely. Revision II is a revision based on the opinions, difficulties and desires of the users. Limited field test revision which is an improvement of media or design based on limited field testing.

7. Main field testing: the main trial involving 20 research subjects. (1) conducting initial field tests on product designs, (2) limited in nature, both in substance of design and parties involved, and (3) initial field tests are carried out repeatedly in order to obtain a feasible design, both substance and methodology.

8. Main product revision: make improvements / enhancements to the wider trial results, so that the product being developed is already an operational media design that is ready to be validated. Revision of Broader Field Test Results: this step is the second improvement after a wider field test is carried out than the first field test.

9. Final Product Revision: validation test of the operational media that has been produced. Final Revision of Feasibility Test Results. This step will further refine the product being developed which includes (1) conducting a test of the effectiveness and adaptability of the basic technique of starting in the form of a module (manual) with video. (2) testing the effectiveness and adaptability of learning materials. Basic techniques start in the form of modules (manuals) equipped with videos involving potential product users, and (3) the results of field tests are that a design media is obtained that is ready to be applied, both in terms of substance and methodology.

10. Dissemination and implementation: disseminating the developed product / media. Report on the results of $\mathrm{R} \& \mathrm{D}$ through scientific forums, or through the mass 
media. Product distribution must be done after going through quality control.

The development of a guide book / module for basic techniques Start in running is deemed necessary so that every student is able to understand every difference of the 3 types of starts in running that can stimulate lecturers and students, including: (1). Teaching styles that are increasingly developing point to students, (2) modules that are always updated according to learning in the era of globalization, (3) learning has standard guidelines, (4) achievement of learning targets is achieved, and (5) the emergence of creativity and innovation in learning. The advantages of using the start technique manual will greatly affect student skills both in terms of movement and learning objectives (IAAF, 2000a; IAAF, 2000b).

In the basic athletic skills course, for example, most of the lecturers have not been able to assess what the actual goals of learning are. Most lecturers only look at the results of the student's running speed without paying attention to the starting stages themselves which are the most important aspects in running competitions.

Didik (2010) defines learning media as a communication medium used in teaching and learning activities. In line with this opinion, Degeng stated that teaching media is a component of the delivery strategy that can be loaded with messages that will be conveyed to the learners, whether they are people, tools, or materials.

From these opinions it can be concluded that learning media is any tool, both hardware and software as a communication medium to provide clarity of information. Learning media facilitate the communication of teachers and students in learning and often media are able to stimulate students' thoughts, attention and desire to learn which encourages students to want to know more about something (Thompson, 2009).

A development in development research is presented in the development procedure section, which usually follows the development adopted by the researcher. Development can also provide a framework for theory development and research. By following a particular model adopted by researchers, a number of inputs will be obtained to improve the resulting product, whether in the form of teaching materials, media, or other products.

The development of the manual for the basic start technique emphasizes students with a model that is easier, more interesting, fun, and not boring so that it can help students learn athletic material easily, especially the basic techniques of starting. consists of basic start techniques that are made in the form of an attractive and innovative book, all products are related to basic start techniques, namely Short Start (Bunch Start), Medium Start and Long Start.

In each product the teacher shows where to position himself so that he can see and improve the product and can convey learning points and progress effectively, so that students can get the best possible benefit from the product.

\section{Trial Subject}

In this research and development, the trial subjects are classified into two, namely the Expert Trial Subject and the Small Group Trial and Field Trial Subject. The material expert in question is Mr. Hardodi Sihombing, M.Pd as a lecturer in the Basic Athletic Skills subject and as a trainer as well as a Medan Athletic athlete at Kmapus STOK Bina Guna. The material expert has a role to determine whether the material in the basic start technique manual is appropriate with the material or not. 
Then the Media Expert in question is Mr. Khirul Usman, M.Pd, who has expertise in the field of media training and education. Media experts play a role in providing input on media ethics and aesthetics.

The technique of determining the test subject in this study was simple random sampling. The meaning of simple random sampling according to Nurhayati \& Widodo (2018) simple random sampling can be done if a list of population names already exists.

The test subjects used were students who took the basic athletic skills course. In the Small Group Trial, 10 students of STOK Bina Guna were used. In the Field Trial using STOK Bina Guna students, totaling 20 people, consisting of trainers and students.

\section{Data Collection Methods and Research Instruments}

To obtain data or information in research, it is necessary to carry out data collection activities. In the data collection process, a data collection tool or instrument is needed. Data collection was carried out in the study using two techniques, namely the preliminary study instrument and the model development instrument and field trials. As for the preliminary study instrument, which was carried out in obtaining information, several methods were carried out including interviews, observation and questionnaires.

\section{Type of Data}

The types of data used in this research are quantitative data and qualitative data. According to Woeryanto (1983) quantitative data is data in the form of numbers or data that has been given a value. While qualitative data is data in the form of sentences or picture. Quantitative data in the form of assessments, collected through a product trial questionnaire or questionnaire, during the testing activities, were analyzed using descriptive quantitative analysis. Percentage is intended to determine the status of something which is then interpreted with a qualitative sentence. The questionnaire used in this study was an assessment questionnaire. Based on the number of opinions or answers, then after that the researcher presents each answer using a formula. After obtaining the percentage with this formula, then the media feasibility of this starting technique manual is classified into four categories of eligibility.

\section{RESULTS AND DISCUSSION}

\section{Presentation of Data}

Presentation of data is divided into a research stage and a development stage. The research stage is carried out by a preliminary study, while the development stage is carried out through product planning, validation and product testing.

\section{Product Planning}

Product design begins with looking for relevant results as a reference for researchers and looking for book references. Then the product design to be developed is discussed with experts in their field to get a design that is in accordance with the material contained in the starting exercise. After the material is approved, the researcher takes pictures in accordance with the approved material. Furthermore, the 
images that have been taken are sorted and editing in the lighting and size sections using Adobe CorelDRAW X7 and Adobe Photoshop CS 6.After editing the image, continue making book products using Adobe in Design CS 6.

\section{Book Specifications}

The product specifications for this Start Basic Technique book are as follows: the size of the Basic Engineering book starts is $148 \times 210 \mathrm{~mm}$, the basic color is green and divides several sections or chapters with various colors, has 82 pages with 7 opening pages, 4 introductory pages, 8 pages of table of contents to glossary of terms, 60 pages for introductory to concluding chapters, 5 pages for bibliography and author's biodata, materials used in the cover use 230 gr ivory paper without being accompanied lamination layer, the contents of the book use 80 gr HVS paper.

Overall, the book media of Basic Techniques (Bunch Start), Medium Start (Medium Start), Long Start (Long Start) for Students of Athletics Subjects is feasible to use after two stages of trials have been carried out. This development research can be used to add references for lecturers and students, coaches, and athletic athletes, as well as the general public in learning more about basic athletic start techniques.

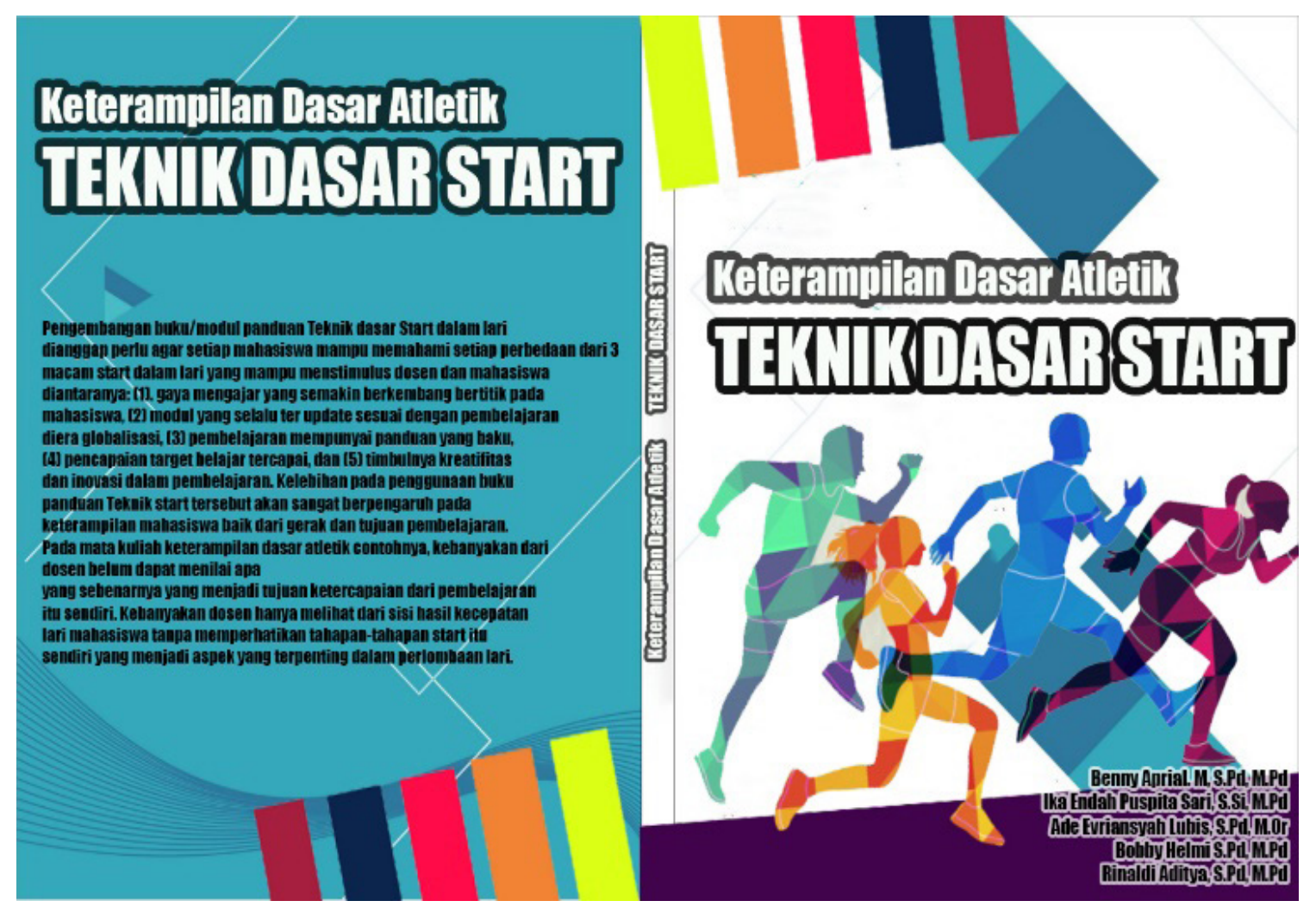

Figure 3. Book Cover of "Ketrampilan Dasar Atletik Tenik Dasar Start"

Based on the results of research and development of the book Basic Technique start (Short Start (Bunch Start), Medium Start, Long Start) For Athletics Subject Students, it can be concluded that product manufacturing begins with a preliminary study stage through observation, in-depth interviews and distributing questionnaires in learning basic athletic skills. Product design begins with discussions with experts in their fields to get a design that fits the material, takes pictures according to the appro- 
ved material, image editing with Adobe CorelDRAW X7 and Adobe Photoshop CS 6, making products with Adobe in Design CS 6. Specifications The resulting product size is $148 \times 210 \mathrm{~mm}$ with a total of 82 pages, the material used for the cover is $230 \mathrm{gr}$ ivory and the contents use 80 gr HVS without lamination on the cover.

The feasibility level of the Basic Technique start (Bunch Start), Medium Start (Medium Start), Long Start (Long Start) for Students of this Athletic Course based on media experts is $94.44 \%$, and the eligibility percentage of Material Experts is $98.5 \%$. Based on the small group trial, it was found that the percentage of calibration was $84.9 \%$ and the field trial was $89.85 \%$. This medium is feasible (Setyawan, 2018).

Based on the results of the research which has stated that the media for the book Basic Technique start (Bunch Start), Medium Start (Medium Start), Long Start (Long Start) are feasible and validated by Media Experts and Material Experts, then there are the following suggestions. For trainers and athletes in order to be able to use the media of the Basic Technique book start as a reference and a variety of basic technical training exercises to start. Students can use this product as a reference in lectures. For the general public it can be used as a new knowledge about karate. For instructional media practitioners, in order to be able to test the level of effectiveness in learning and make learning media more varied. For all athletic athletes, this book can be used as a reference in learning basic starting techniques, and can be used to help memorize basic techniques at home (Lufthansa et al., 2020).

\section{CONCLUSION}

The development of the manual for the basic start technique emphasizes students with a model that is easier, more interesting, fun, and not boring so that it can help students learn athletic material easily, especially the basic techniques of starting. consists of basic start techniques that are made in the form of an attractive and innovative book, all products are related to basic start techniques, namely Short Start (Bunch Start), Medium Start and Long Start. In each product the teacher shows where to position himself so that he can see and improve the product and can convey learning points and progress effectively, so that students can get the best possible benefit from the product.

\section{REFERENCES}

Altuntas, I., Polat, T., \& Ulucan, K. 2020. mikroRNA'ların atletik performansa etkisi. Eurasian Research in Sport Science, 5(1): 103-109.

Bahagia, Y. 2012. Pembelajaran Atletik. Jakarta: Direktorat Jendral Pendidikan Dasar Dan Menengah.

Bompa, P. 2009. Theory and methodology of training. United State of America: Human Kinetics.

Brog. W. R \& Gall, M. D. 1983. Education Research An Introduction. New York: Longman.

Fareira, H. 2014. Peningkatan Hasil Belajar Lari 100 Meter Melalui Pendekatan Bermain. Jurnal Ilmu Keolahragaan, 13(1): 44-59.

Fakhrianto, D.R. 2018. Efisiensi Gerak Tolakan Sudut $70^{\circ}$ dan Sudut $90^{\circ}$ pada Start Jongkok Lari Sprint 20 Meter. Undergraduate Thesis. Malang: Universitas Negeri 
Malang.

IAAF. 2000a. Lari, Lompat, Lempar. Jakarta: IAAF-RDC.

IAAF. 2000b. Pedoman Menagajar Lari, Lempar, Lompat-Level 1. Jakarta: IAAF-RDC. Ishak, A. 2016. Dasar-Dasar Penelitian Olahraga. Jakarta, Indonesia: Kencana.

Kridasuwarso, B. 2016. Analisis Biomekanika Olahraga dan Belajar Motorik pada Start Jongkok Lari Gawang. Presented in Seminar dan Lokakarya Fakultas Ilmu Keolahragaan Universitas Negeri Jakarta. 1 December.

Kurniawan, A., \& Hayudi. 2018. Pengembangan Buku Ajar Strategi Pembelajaran Pendidikan Jasmani melalui Olahraga Permainan Kecil. Jurnal Kejaora (Kesehatan Jasmani dan Olah Raga), 3(2): 178-187.

Lufthansa, L., Saputro Y.D., \& Kurniawan, R. 2020. Pengembangan buku ajar psikologi olahraga berbasis android untuk meningkatkan motivasi belajar dan kemampuan berpikir kritis mahasiswa. Jurnal Pendidikan Jasmani Indonesia, 16(2): 214-223.

Lukman, O.T. 2003. Biomekanika-Penerapan Hukum dan Prinsip Mekanika. Surabaya: UNESA.

Muhtar, Tatang, \& Irawati, R. 2009. Atletik. Sumedang: UPI Sumedang Press.

Nurhayati, C. D. L., \& Widodo, A. 2018. Analisis Gerak Nomor Lari Sprint 100 Meter Putra Cabang Olahraga Atletik (Studi Kasus Pada Usain Bolt Di Kejuaraan International Association Of Athletics Federation Berlin Tahun 2009). Jurnal Kesehatan Olahraga, 6(2).

Didik, Z.S. 2010. Mengajar dan Melatih Atletik. Bandung: Rosda.

Sugiyono. 2008. Metode Penelitian Kuantitatif, Kualitatif dan $R \& D$. Bandung: Alfabeta.

Setyawan, T. 2018. Pengembangan Buku Ajar Pendidikan Jasmani dan Olahraga Melalui Pendekatan Saintifik Kelas IV SDN Nguter 02 Lumajang. Jp. Jok (Jurnal Pendidikan Jasmani, Olahraga Dan Kesehatan), 1(2): 24-46.

Syarifuddin, A. 1992. Atletik. Jakarta: Departemen Pendidikan Dan Kebudayaan Direktorat Jendral Pendidikan Tinggi Proyek Pembinaan Tenaga Kependidikan.

Thompson, P. J. L. 2009. Intoducing to coaching. IAAF coaching education and certification system.

Woeryanto. 1983. Melatih Atletik. Jakarta: KONI. 